\author{
Mariia Gladun \\ Senior lecturer in Chair of Information Technology and Mathematical sciences \\ Faculty of Information Technology and Management, \\ Borys Grinchenko Kyiv University, Kyiv, Ukraine \\ m.gladun@kubg.edu.ua \\ ORCID: 0000-0003-0293-5670
}

\author{
Dariya Nastas \\ Researcher of IT in Education Laboratory \\ Borys Grinchenko Kyiv University, Kyiv, Ukraine \\ d.nastas@kubg.edu.ua \\ ORCID: 0000-0002-9008-8100
}

\author{
Svitlana Spivak \\ Senior lecturer in Chair of Information Technology and Mathematical sciences \\ Faculty of Information Technology and Management, \\ Borys Grinchenko Kyiv University, Kyiv, Ukraine \\ s.spivak@kubg.edu.ua \\ ORCID: 0000-0002-2249-4473
}

\title{
FORMATION OF DIGITAL COMPETENCE OF FUTURE TEACHERS OF ELEMENTARY SCHOOL USING BLENDED LEARNING AND PERSONAL LEARNING ENVIRONMENT
}

\begin{abstract}
The article is devoted to the issue of formation and increasing digital competence of future primary school teachers. The article addresses the issue of the implementation of blended learning in higher education, analysis methods and software applications with which scientific and teaching staff engaged in educational activities. The characteristic features and needs of the new generation $\mathrm{Z}$ have been determined, the concepts of macro, meso and micro trends in European education have been analyzed. The authors discovered the meaning of Personal learning environment (PLE), substantiated the idea that giving students the opportunity to work in a qualitatively formed e-environment will allow them to acquire professional and soft-skills for later life, create their own e-portfolio, manage their own educational formal and informal learning process throughout life. There are highlighted and described the characteristic features of informal learning in the article. The emphasis in the work is on the personalization of educational trajectories of students, thanks to PLE tools. The use of ICT, in particular, network services, allows us to create the appropriate pedagogical and technological basis for the maintenance of modern informational systems of educational purposes, which are the priority in the basis of any educational process, the formation of digital competence, and the effective organization of the educational environment of an educational institution.
\end{abstract}

Keywords: personal learning environment; social network services; virtual educational environment in high school; modern educational trends; digital competence; formal and informal learning.

The 21 st century is proclaimed as the era of an information society when information and knowledge are produced in a single information space. Characteristic features of information society include: increasing the role of information and knowledge in the life of society; an increase in the number of people engaged in information technology, communications and the production of information products and services; the growth of informatization and the role of information technology in social and economic relations; creation of a global information space that provides effective information interaction of people, their access to world information resources and satisfying their needs for information products and services.

Taking into account the modern tendentious and innovative changes in the educational environment, it is increasingly becoming a task to form a productive learning environment in the context of a blended form of education, when higher education institutions and its 
scientific and teaching staff are able to establish productive cooperation with a student both remotely and during full-time sessions.

The relevance of the scrutiny lies in the fact that information and communication technologies are actively used by people in all spheres of its activity, including education. So, today there is the issue of using information and communication technologies based on the introduction of cloud technologies, is one of the most promising innovative directions for the development of network services of information and communication technologies. Cloud Computing is a paradigm of modern ICT development that provides distributed and remote processing and storage of data. The use of cloud technologies makes it possible to create proper pedagogical and technological basis for the maintenance of modern information systems for educational purposes, which are the priorities in ensuring any educational process, as well as the effective organization of the educational environment of an educational institution in a blended learning.

The purpose of the article. Consider modern cloud services for shaping the digital competence of future primary school teachers in mixed learning, justify scientifically the educational potential of using a personal learning e-environment to meet the needs of formal and non-formal learning.

The rapid development of ICT introduces new requirements for modern higher education, in particular, the design and development of a modern open-cloud, cloud-based educational environment of the university, which takes into account the needs and peculiar properties of the use of ICT for all subjects of the university's educational process (on the one hand, students, and on the other - teachers and managers) who are different generations and have different needs and peculiarities, different levels of IC competence and different understanding and vision of educational policy.

Such task becomes especially relevant at the time of widespread e-education and open courses MOOC, which become a catalyst for qualitative changes in the development of university education, since on the one hand they support the natural competition of modern universities, teachers, teaching systems and innovative pedagogical technologies, and on the other hand - promote the spread of non-formal education, especially taking into consideration current trends (Morze, Spivak, Smyrnova-Trybulska, 2014, pp. 158-166). Taking into account such tendencies, we can formulate the hypothesis that the quality of the e-learning environment of a modern educational institution should be based on the study of the needs of its students, the content and technologies that they use to create and maintain their own personal educational environments. The filling of this educational environment, the quality of its content and the effectiveness of its use by students to achieve the goals of studying and training future competitive specialists for the modern labor market depends on the level of IC competence of the teachers and students, as well as the coincidence of the services they use.

Analysis of recent research and publications. The main target of training a specialist in the socio-economic conditions of the information society is not getting his qualification in the chosen specialist field, but the gain and progress of certain competences that should enable him(her) to adapt in the conditions of the dynamic development of the modern world. It should be noted that competence is considered as a set of interrelated personality qualities (knowledge, skills, attainments, methods of activity) regarding a certain range of necessary subjects and processes for high-quality productive activity (Morze, Smyrnova-Trybulska, Kommers, Gladun, Zuziak, 2017, pp. 296-312).

Modern pedagogical circles understand the competence as a dynamic combination of knowledge, ways of thinking, views, values, skills, abilities, and other personal qualities, which determines the ability of a person to conduct professional and / or further educational activities successfully (Morze, Spivak, Smyrnova-Trybulska, 2014, pp. 158-166). Among the key person's competences is digital one, which is seen in the conscious and critical use of 
technologies by the digital society for work, leisure and communication. (Information Society Technology (IST). Exactly in this context, the European organizations and institutions, including the European Research Center (JRS) announced an execution strategy and support of a number of studies and initiatives entitled "Learning and Skills for the Digital Era", which are designed to create tools for different categories of professionals in order to summarize the world-wide, European experience of 21st century skills for using ICT in education and work. This strategy has developed and presented by the important document of European commission - DigComp 2.0: Digital Competence Framework for Citizens, which includes specifications of descriptors and levels of mastering the digital competence. Digital Competence Framework 2.0 includes the following levels: Basic User, Independent User, Professional User (Vuorikari, Punie, Carretero Gomez, Van den Brande, 2016). It outlines five areas of such competence: information and digital literacy, communication and collaboration, digital content creation, security, problem solving. Framework 2.1, updated in 2017, contains descriptors of eight levels of mastering. The eight levels of mastering each competency have been defined in the form of learning outcomes (using the verbs of action, according to Bloom taxonomy) using the formulation which is proposed by the European Qualifications Framework (EQF). Each level description contains the knowledge, skills and abilities described in one descriptor for each level of competence: that is, 168 descriptors $(8 \mathrm{x}$ 21 learning outcomes). The framework of the digital competence has the following structure: fields (defined as components of digital competence - there are five of them); descriptors and competency names (relevant to each field); literacy levels (for each competency); examples of knowledge, skills and attitudes (applied to each of the competencies). To find out more about the framework you can follow the link https://ec.europa.eu/jrc/en/digcomp/digitalcompetence-framework.

In the formation of digital competence, the selection and use of innovative pedagogical technologies and forms of educational process is an important issue. Studying at a high school plays an important role in the formation of a competitive specialist, but formal learning can not pay respect to all the specifics of the future worker's professional training, but only provides the basis for the further self-development and practical training of a particular profession. Unlike traditional formal education, non-formal learning fully takes into account personally-oriented human needs and facilitates the rapid and easy acquisition of certain knowledge anytime and anywhere. Some experts argue that $80 \%$ of people acquire knowledge through non-formal learning and the accumulation of this knowledge is primarily through collaboration at work or study, which makes using non-formal learning the ideal means for maximizing the use of learning activities. Non-formal learning has to be carried out through a set of electronic content and modern web services and software applications, on which individual educational electronic platforms are based for content management and the implementation of electronic communication, cooperation and solving educational and scientific problems, and which enable the student to establish educational goals independently and manage their own process of monitoring educational achievements, as well as, based on the portfolio method, to form their own e-learning space, create their own electronic library, to make and promulgate educational and scientific project activities, etc. Exactly aggregate of electronic content and modern web services and software applications like this can be called Personal learning environment (PLE) - a personalized electronic learning environment. The polyfunctionality of the PLE will enable the student to acquire knowledge efficiently and effectively during formal and informal learning using modern cloud, web technologies and open educational resources (Spivak, 2014, pp. 10-14).

PLE construction is based on the use of cloud technologies (SAAS - Software As A Service). Access to learning becomes an entrance to resources and services, and allows students not only to use learning resources, but, more importantly, to create them. Learning in 
this way turns from the transfer of information and knowledge to their creation. The PLE feature is that it becomes a tool that allows students to participate in a distributed environment, which consists of a network of people, services and resources. PLE is not only a convenient environment for performance of activities, but a means of creating a personal learning network where you can collaborate not only with the direct subjects of the educational process but also with their communities, which allows you to significantly expand the circle of communication, go beyond the formal communication and receive much more professional information.

The quality of the learning process depends on the design of a PLE, which takes into account its use - it should be simple and effective. By choosing tools to work in a PLE, the student is personally involved, the content of the medium depends only on the level of the IC's competence, which must be constantly growing and replenished with the knowledge and skills of using new social services. That is why one of the University's tasks is to develop the students' IC competencies continuously through the use of new cloud-based learning services by teachers in the learning process and the introduction of appropriate corporate standards, in particular, for PLE both to a student and teacher.

PLE allows you to create a personal learning network and manage knowledge (Kukharenko, 2013). According to Gasevic and others (Gasevic, Kovanovic, Joksimovic and Siemens, 2014), this is the most effective knowledge management system.

Having analyzed various cloud services and electronic resources, we came to the conclusion that the most optimal and easiest way to create an e-learning space for a student that takes into account formal and informal learning components is to use the Microsoft Office 365 Education Company, namely the OneNote Class Notebook application created specifically for the organization of the study space of the academic group, and contains a teacher's notebook, a notebook for a collaborative work, and a personal notebook for each student, thus zoning the electronic learning space into three parts: general purpose, space for cooperation and personal space. Convenient is that the notebooks are saved automatically, which speeds up the work of all subjects of the educational process and prevents loss of data, as well as they can be viewed from any device both online and offline mode (Spivak, 2018, pp. 83-90).

For the experiment students of the specialty "Elementary Education" were selected during the study of the following subjects: "ICT in education" (2nd year), "Methodology of computer science" (4th year, 6th year), "Special Workshop On Computer Science" (4th year), " Special course on informatics "(4 year, 6 year). In order for the future specialist to apply information and communication technologies in his professional activity systematically, we proposed students do laboratory work and practical tasks in different cloud-oriented services with the ability to create their own e-content.

Almost all cloud-based services have functions for collaborative and distributed work using any social network. Through the study of ICT in education, we offer students to get acquainted with the wide functionality of Google platforms (Gmail, Google Groups, Google Calendar, Google Forms) and Microsoft Office 365 (Forms, Planner, Project). The most popular cloud-based services among students during the study of the discipline "Methodology of Computer Science" are Google Drive, Google Docs, Google Presentations, Google Classroom, SharePoint. For a brain attack, students liked various virtual boards (Flockdraw, Twiddla, En.linoit, Padlet, etc.). During studying the discipline "Special Workshop On Computer Science" we try to pay much attention to art, creativity and self-expression of the student. Since a significant amount of hours is spent on independent work of students, at one of the first practical classes they receive a list of three categories of free cloud-oriented services: interactive publications and e-books; dynamic presentations; animated video. Students distribute the services listed in the list among themselves and supplement them with 
a brief description, a video instruction and references to finished examples of works. Later, students are offered a questionnaire (we use Kahoot), the results of which the teacher takes into account during the planning of further work within the discipline, since the questionnaire shows which of the proposed cloud-oriented services students want to work with during the study of discipline. Often, the choice of students is Calameo (it allows you to instantly create interactive publications), Ourboox (creating e-book with unique content with links to other resources), Emaze (presentation with three-dimensional transitions and bright themes for design), Moovly (animated presentations in which users have access to animation, graphics, texts, interactive elements, video and audio, etc.), Prezi (nonlinear presentations with a map, schematic overview, which allows users to move between themes (optional), enlarge the details and drag context) and PownToon or GoAnimate (to create short cartoons). During the course "Special Workshop On Computer Science" we teach future teachers of elementary school to create educational multimedia content and supplement teaching of disciplines with real experiments and projects through the educational portal Go-Lab. In order for future teachers of the elementary school to be freely oriented to the edge of innovative technologies and software applications in the last class of the discipline "Methodology of Informatics Training", we offer practical work, during which the student independently explores cloudbased services, develops his/her classification and defines the training courses on which service can be used.

After completing the study of disciplines which include laboratory work and practical tasks using cloud-oriented services, the student knows not only the main technical stages of work with cloud-based services, but also clearly understands the psychological and pedagogical, technical, technological, aesthetic, functional and ergonomic requirements for multimedia content.

For students of the specialty "Elementary Education", at the final stage, a questionnaire "Cloud-oriented services in professional activity" was conducted. The research was attended by almost 100 respondents, among which 54\% were students of Full-time education, and $46 \%$ - of the extramural studies.

To the question about the need to use cloud-based services to create educational content for elementary school students, almost all gave a positive answer (Img. 1).

93 відповіді

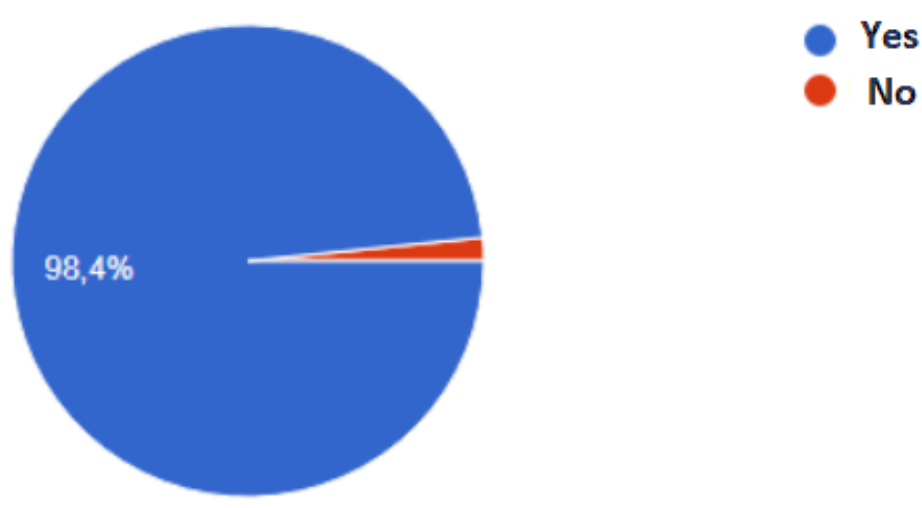

Fig. 1. Do you need to use cloud services to create educational content for elementary school students?

At the same time, understanding the great educational potential of cloud-oriented services, students are clearly aware of the problems they will have to face (Img. 2). The most 
popular responses were: "Not all schools have the necessary technical support", "In my opinion, there are problems of applying only the technical nature", "The problem is that not all teachers have an adequate level of mastering ICT", "Not all students will be able to work with services in extra time" and so on (Nechyporenko, Nastas, 2018).

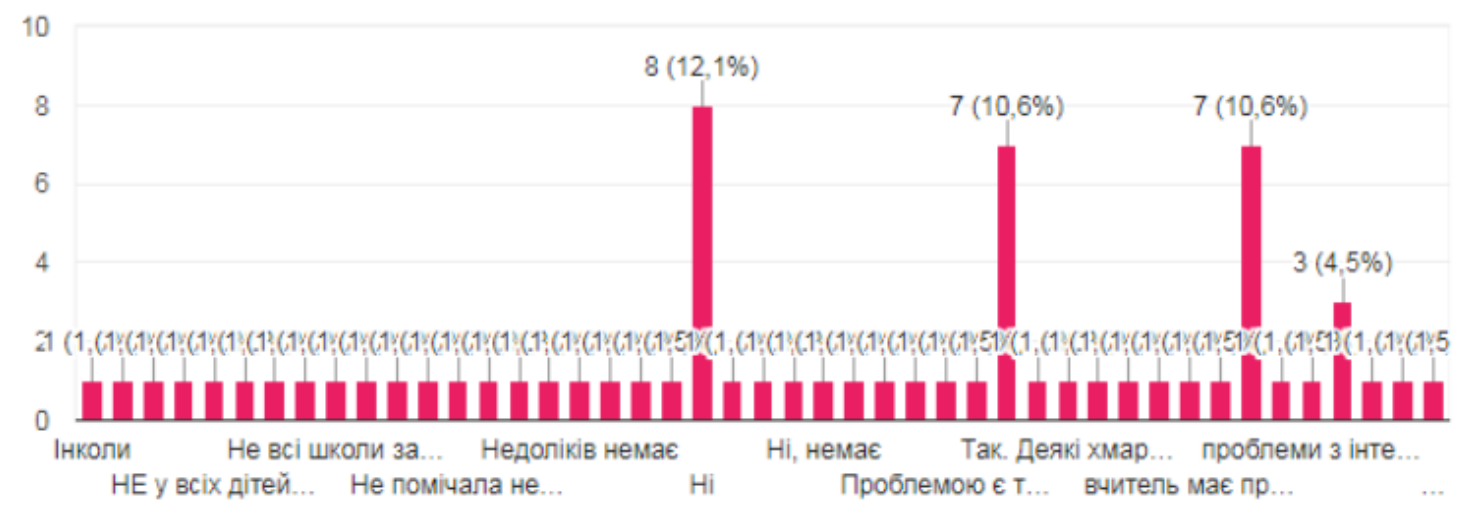

Fig. 2. What problems do you encounter when using cloud-oriented services?

PLE has demonstrated multidisciplinarity, since the main task of designing such medium is to enable the student to receive correct, timely and verified information in a format that is convenient for him/her at any given time. The teacher can independently determine the environment which the students will connect to and the means for cooperation, communication.

After conducting educational activities, we concluded that PLE tools should be grouped according to the following main activities of students in the learning process: organization, search, publication, collaboration, communication, cloud storage services (Morze, Spivak, 2014, pp. 231-240).

The results of the questionnaire "PLE as a means of personalization of education" among students who studied with the help of a formed and supervised environment noted that they significantly increased their interest in discipline, as they have felt the modernity of teaching approaches. Also, many of them noted that using social networks which they were accustomed to, communication with the teacher was easier and much fearless. The students also liked the fact that enormous amount of tasks were designed such way that they needed to be united and seek common solutions, and as a result, it led to the development of communication skills, tolerance and patience. Also, the vast majority of respondents noted that such environment is incredibly convenient, since access to learning resources is 24 hours per day, which allows them to repeat the material they have trained, to do tasks and to carry out educational activities at a convenient time.

After completing the study of the disciplines, we want to note that the teacher should have a basis for working with students but should select tools for each study group individually, depending on the preferences of the majority, it is also necessary to accompany the training with specific instructions which specify what student must learn, which means to use and how to protect the work. Another difficulty may be that the teacher should be accessible not only during classes but also throughout the course of studying the discipline, since students need consultations and can write their own questions, wishes and clarify some of the educational moments at any convenient time for them.

Conclusions. The transition of the Ukrainian educational system to the 21 st century paradigm "life-long education", the increase of the popularity of distance learning and the introduction of the European Credit Transfer System (ECTS) into the curriculum, in its 
conditions provides for the provision of individual and independent student work, depending on the content of the discipline and the specifics of the student's activities, from $25 \%$ to $60 \%$ of the hours allocated for mastering a certain discipline (Rashkevuch, 2014, pp.17-18). Such a substantial percentage can not be left out of the attention of both the object and the subject of learning. And it allows the student to effectively acquire knowledge during formal, nonformal and informal learning, independently manage content and implement electronic communication, collaborate and solve educational and scientific problems, and provides the opportunity to establish educational goals independently and manage their own process of monitoring academic achievements, as well as, create their own e-learning space based on the portfolio method. During developing their own PLE, the student improves their digital skills.

\section{REFERENCES}

Morze, N., Spivak, S. \& Smyrnova-Trybulska, E. (2014). Personalized Educational Environment - As one of the trends of modern education. Information and Communication Technology in Education, 158-166. ISBN 978-80-7464-561-7.

Morze, N., Smyrnova-Trybulska, E., Kommers, P., Gladun, M. \& Zuziak, W. (2017). Selected aspects and conditions of the use of robots in STEM education for young learners as viewed by teachers and students Interactive Technology and Smart Education, 14 (4), 296312. ISSN 1741-5659

Vuorikari, R., Punie, Y., Carretero Gomez S. \& Van den Brande, G. (2016). DigComp 2.0: The Digital Competence Framework for Citizens. Update Phase 1: The Conceptual Reference Model. Luxembourg Publication Office of the European Union. EUR 27948 EN. doi:10.2791/11517

Spivak, S. (2014). The relationship between formal and informal learning in creating a personalized e-learning environment for a modern student. Informatyka ta informacijni tekhnologhiji $\mathrm{v}$ navchaljnykh zakladakh: naukovo-metodychnyj zhurnal. K.: Vyd. tov. «Svitoch», № 3 (51), 10-143. (in Ukrainian)

Slideshare (2013). Kukharenko V. Didactics of mass open online courses. Sep 26, 2013. http://www.slideshare.net/kvntkf/mooc-omsk (in Ukrainian)

Gasevic, D., Kovanovic, V., Joksimovic, S. \& Siemens, G. (2014). Where is research on massive open online courses headed? A data analysis of the MOOC Research Initative. The International Review of Research in Open and Distance Learning, 15, 5, 134-175. http://www.irrodl.org/index.php/irrodl/article/view/1954/3099

Spivak, S. (2018). Using cloud-oriented personalized education environment in the organization of educational process. Open Educational E-environment of modern university. №4, 83-90. ISSN 2414-0325 (in Ukrainian)

Nechyporenko, K. \& Nastas, D. (2018). The preparation of students of specialty "primary education" to construction multimedia educational resources by tools of cloudoriented services, Visnyk KNU imeni Tarasa Shevchenka. Serija: pedaghoghika, №2 (8), 4952. ISSN 2415-3699

http://pedvisnyk.knu.ua/index.php/pedvisnyk/article/view/74/71 (in Ukrainian)

Morze, N. \& Spivak, S. (2014). Informal learning as an integral part of e-learning environment of the modern education In: 6th Annual International Scientific Conference Theoretical and Practical Aspects of Distance Learning „E-learning and Intercultural Competences Development in Different Countries“ Conference Proceedings, Ed. Wiesław Banyś, Zenon Gajdzica, Urszula Szuścik, University of Silesia in Katowice (Poland), 231240. ISBN: 978-83-60071-76-2.

Rashkevuch Y. (2014). The Bologna Process and the New Paradigm of Higher Education: A Monograph. Vydavnytstvo L'vivs'koï politekhniky, 17-18. (in Ukrainian) 
Text of the article was accepted by Editorial Team 16.11.2018

\section{ФОРМУВАННЯ ІК-КОМПЕТЕНТНОСТІ У МАЙБУТНІХ ВЧИТЕЛІВ ПОЧАТКОВИХ КЛАСІВ В УМОВАХ ЗМІШАНОЇ ФОРМИ НАВЧАННЯ}

\section{Гладун Марія Анатоліївна}

старший викладач кафедри Комп’ютерних наук і математики

Факультет інформаційних технологій та управління

Київський університет імені Бориса Грінченка м. Київ, Україна

m.gladun@kubg.edu.ua

ORCID: 0000-0003-0293-5670

\section{Настас Дар'я Леонідівна}

Науковий співробітник НДЛ інформатизації освіти

Київський університет імені Бориса Грінченка м. Київ, Україна

d.nastas@kubg.edu.ua

ORCID: 0000-0002-9008-8100

\section{Співак Світлана Михайлівна}

старший викладач кафедри Комп’ютерних наук і математики

Факультет інформаційних технологій та управління

Київський університет імені Бориса Грінченка м. Київ, Україна

s.spivak@kubg.edu.ua

ORCID: 0000-0002-2249-4473

Анотація. Статтю присвячено актуальній проблемі розвитку та підвищення рівня сформованості ІК-компетентності майбутніх вчителів початкових класів. Порушено тему впровадження змішаного навчання у закладах вищої освіти, проаналізовано методи та програмні застосунки за допомогою яких науково-педагогічні працівники здійснюють освітню діяльність. Визначено характерні ознаки та потреби у навчанні нового покоління Z, проаналізовано концепції макро-, мезо- та мікро-трендів у європейській освіті. У статті розкрито зміст поняття Personal learning environment (PLE), обгрунтовано ідею про те, що надання студенту можливості працювати у якісно сформованому е-середовищі дозволить йому не лише оволодіти професійними навичками, а й здобути soft-skills для подальшого життя, та, враховуючи освітні парадигми XXI століття, створити власне е-портфоліо, керувати власним освітнім процесом як за формального, так і за неформального навчання продовж усього життя. Виділено й описано характерні особливості неформального навчання. Основну увагу в роботі акцентовано на персоніфікації освітніх траєкторій студентів, завдяки засобам PLE. Використання IKT, а зокрема мережних сервісів, дозволяє створити належний педагогіко-технологічний базис супроводу сучасних інформаційних систем навчального призначення, що $є$ пріоритетними в основі забезпечення будь-якого освітнього процесу, а також ефективну організацію роботи навчального середовища освітнього закладу.

Ключові слова: персональне навчальне середовище; соціальні мережні сервіси; віртуальне освітне середовище ЗВО; сучасні освітні тренди; ІК-компетентності; формальне та неформальне навчання 